\title{
Revised identification of tropical oceanic cumulus congestus as viewed by CloudSat
}

\author{
S. P. F. Casey ${ }^{1,{ }^{*}}$, E. J. Fetzer ${ }^{1}$, and B. H. Kahn ${ }^{1}$ \\ ${ }^{1}$ Jet Propulsion Laboratory, Pasadena, CA, USA \\ * now at: Earth System Science Interdisciplinary Center/Joint Center for Satellite Data Assimilation, \\ College Park, MD, USA
}

Correspondence to: S. P. F. Casey (sean.casey@noaa.gov)

Received: 25 January 2011 - Published in Atmos. Chem. Phys. Discuss.: 17 May 2011

Revised: 6 December 2011 - Accepted: 5 February 2012 - Published: 13 February 2012

\begin{abstract}
Congestus cloud convective features are examined in one year of tropical oceanic cloud observations from the CloudSat/CALIPSO instruments. Two types of convective clouds (cumulus and deep convective, based on classification profiles from radar), and associated differences in radar reflectivity and radar/lidar cloud-top height are considered. Congestus convective features are defined as contiguous convective clouds with heights between 3 and $9 \mathrm{~km}$. Three criteria were used in previous studies to identify congestus: (1) CloudSat and CALIPSO cloud-top heights less than $1 \mathrm{~km}$ apart; (2) CloudSat $0 \mathrm{dBZ}$ echo-top height less than $1 \mathrm{~km}$ from CloudSat cloud-top height, and (3) CloudSat $10 \mathrm{dBZ}$ echo-top height less than $2 \mathrm{~km}$ from CloudSat cloud-top height. A majority of congestus convective features satisfy the second and third requirements. However, over $40 \%$ of convective features identified had no associated CALIPSO cloud-top height, predominantly due to the extinguishment of the lidar beam above the CloudSat-reported convective cloud. For the remaining cells, approximately $56 \%$ of these satisfy all three requirements; when considering the lidar beam-extinction issue, only $31 \%$ of congestus convective features are identified using these criteria. This implies that while previous methods used to identify congestus clouds may be accurate in finding vigorous convection (such as transient congestus rising toward the tropopause), these criteria may miss almost $70 \%$ of the total observed congestus convective features, suggesting a more general approach should be used to describe congestus and its surrounding environment.
\end{abstract}

\section{Introduction}

Johnson et al. (1999) noted that tropical oceanic convective clouds can be grouped into three categories: shallow cumulus, with cloud-top heights near the trade inversion 1$2 \mathrm{~km}$ above the surface; mid-level cumulus congestus clouds, with cloud tops near the $0^{\circ} \mathrm{C}$ melting level; and deep cumulonimbus clouds, with cloud-tops near the tropopause. While shallow and deep convection have long been acknowledged, the role of mid-level cumulus congestus has only recently become recognized. Kikuchi and Takayabu (2004) identified the cloud types with different stages of the MaddenJulian Oscillation (MJO) as (1) a "suppressed stage" with few clouds; (2) a "shallow convective stage" with shallow clouds; (3) a "developing stage" with cumulus congestus clouds; (4) a "mature stage" with deep convective clouds, and (5) a "decaying stage" with anvil clouds. Similarly, Mapes et al. (2006), Chen and Del Genio (2009) and Tromeur and Rossow (2010) noted increased occurrence of congestus clouds prior to peak rainfall events associated with deep convection. Despite the observational evidence of congestus clouds, however, they were not accurately reproduced in general circulation model parameterizations until recently (Khouider and Majda, 2006; Sherwood et al., 2010).

The spatial coverage of satellites allows for identification of characteristics of congestus clouds globally. Low-earth orbit satellite observations, as from CloudSat and CloudAerosol Lidar and Infrared Pathfinder Satellite Observation (CALIPSO) (Stephens et al., 2008; Winker et al., 2009) can provide fine spatial resolution measurements of congestus cloud features despite the limitations of analyzing convective life-cycle (Luo et al., 2009). Automated methods for identifying congestus would simplify understanding of regional 
differences in congestus populations, connections to surface and environmental conditions, and applications to tropical climatology and many other important areas of research.

Methods for identifying congestus, however, have varied. Johnson et al. (1999) identified congestus as precipitating convective clouds with cloud-top heights between 5 and $9 \mathrm{~km}$. Rossow et al. (2005) used a cloud-clustering algorithm of joint frequency distributions of cloud top pressure and optical thickness, defining 2 of the 6 obtained convective "weather states" as associated with congestus. Jensen and Del Genio (2006) defined convective clouds with cloud-top heights between 3 and $9 \mathrm{~km}$ as congestus, including convective cells in the lower free troposphere identified as shallow clouds by Johnson et al. (1999).

Recently, Luo et al. (2009) have identified congestus using reflectivity and cloud-height information from CloudSat and CALIPSO. Congestus observations were defined as clouds with cloud-top heights (CTH) between 3 and $9 \mathrm{~km}$ (Jensen and Del Genio, 2006) and with continuous radar echo from CTH to near the ground which satisfy three criteria: (1) difference between CloudSat and CALIPSO CTH of less than $1 \mathrm{~km}$, (2) difference between CloudSat CTH and $0 \mathrm{dBZ}$ echotop height $(\mathrm{ETH})$ of less than $1 \mathrm{~km}$, and (3) difference between CloudSat and $10 \mathrm{dBZ}$ ETH of less than $2 \mathrm{~km}$. These values were identified in Luo et al. (2008) as cloud and echo characteristics shared by a majority of deep convective clouds. Luo et al. (2009) also included a method for determining the convective buoyancy of CloudSat-viewed convection; this approach is useful for determining whether an observed convective cloud is "terminal", remaining at congestus heights, or "transient", rising to become deep convection. However, this method has not been verified with independent observations, and as such this paper will not include this method.

This study relates the CloudSat-provided cloud classification data to radar and lidar characteristics of mid-level tropical oceanic convection. We then compare these statistics to those utilized by Luo et al. (2009), and assess how well the Luo et al. (2009) criteria capture congestus.

\section{Methodology}

Clouds are identified using data measured in 2008 (full year) from two A-train satellite instruments. The Cloud Profiling Radar (CPR) onboard CloudSat (Stephens et al., 2008) transmits at 94-GHz (W-band) and had a verified beginningof-life sensitivity of $-30 \mathrm{dBZ}$ (Tanelli et al. 2008). It is a nadir-viewing instrument with an effective horizontal resolution of $1.4 \times 1.7 \mathrm{~km}$. Three data release R04 products provided by the CloudSat science team will be used. First, the main 2B-GEOPROF (Marchand et al., 2008) product gives cloud mask/certainty information as well as radar reflectivity values. Next, the 2B-GEOPROF-LIDAR product (Mace et al., 2009) combines CPR data with measurements from the Cloud-Aerosol Lidar with Orthogonal Polarization (CALIOP) lidar onboard CALIPSO. This product interpolates CALIPSO high-resolution data onto the CloudSat footprint. As CALIPSO passes over the same location $15 \mathrm{~s}$ after CloudSat, the measurements can be assumed to be simultaneous. The latest version of the 2B-GEOPROF-LIDAR product as of the time of this paper's resubmission (P2_R04) will be used here.

Finally, the cloud classification (2B-CLDCLASS) product will be used. Two types of convection are identified using the 2B-CLDCLASS algorithm (Sassen and Wang, 2008); a "cumulus" flag that identifies areas of low- to medium-level convection, and a "deep convection" flag that identifies convective cells with cold cloud-tops $(T<258 \mathrm{~K})$ using reanalysis temperatures. As we are interested in tropical oceanic regions, we limit our study to areas between $15^{\circ} \mathrm{S}$ and $15^{\circ} \mathrm{N}$ labelled as ocean by the CLDCLASS product.

Congestus clouds are defined here by two criteria. First is a cloud-top height $(\mathrm{CTH})$ between 3 and $9 \mathrm{~km}$, utilized in Jensen and Del Genio (2006). We impose a second requirement of cloud base to be within $1 \mathrm{~km}$ of the surface; this ensures the cloud in question is related to surface-driven processes while taking into account the ground clutter issues in the lowest $1 \mathrm{~km}$ of CloudSat data (Tanelli et al., 2008). Three levels of radar-detected CTH are considered, based on the degree of certainty of cloud detection in the 2B-GEOPROF product: cloud mask $=40$ marks the most certain cloud detection, while cloud masks 30 and 20 mark decreasing areas of certainty. A comparison of these three cloud mask values is included in this study to see how the choice of cloud mask can affect the cloud statistics obtained from CloudSat. If a field-of-view has a cloud mask of 20 and 30, but not 40, this convective area will be included in the cloud mask 20 and 30 statistics, but not in the cloud mask 40 statistics. Because of this, more convective fields-of-view will be considered for cloud mask 20 statistics than cloud mask 40. As CloudSat measurements are reported on a distance vs. Height grid, these three CTH values are calculated from the reported 2D cloud-mask grid (more information in Marchand et al., 2008).

A fourth $\mathrm{CTH}$, as identified in the GEOPROF-Lidar product as being observed by CALIPSO, is also considered. As will be made clear in the next section, not all observed convection contains a concurrent CALIPSO CTH, even when the CALIPSO lidar is operational. This is due to one of two factors; (1) CALIPSO does not always report a cloud when CloudSat sees one. This is most likely due to an issue with the averaging of multiple CALIPSO FOVs onto the CloudSat FOV in the case of broken cloud cover. (2) The lidar beam may be extinguished by clouds above the convection. If this happens, or if the remaining signal-to-noise ratio on the convective cloud as observed by CALIPSO is low, the convective cloud is flagged in the 2B-GEOPROF-LIDAR product as being observed by CloudSat only. 
Table 1. CALIPSO minus CloudSat CTH differences for individual congestus fields-of-view, and mean differences between CloudSat CTH and ETH, separated by the six cloud classification/mask categories. Column 4 also lists the percent of cases where CALIPSO identifies a cloud top for the same convective cloud viewed by CloudSat; columns 5 and 6 list the percent of cases where a 0 or $10 \mathrm{dBZ}$ echo, respectively, is identified.

\begin{tabular}{|c|c|c|c|c|c|}
\hline $\begin{array}{l}\text { Cloud } \\
\text { classification }\end{array}$ & $\begin{array}{r}\text { Cloud } \\
\text { mask }\end{array}$ & Counts & $\begin{array}{r}\Delta H \\
\text { (CALIPSO-CloudSat) }\end{array}$ & $\begin{array}{r}\Delta H \\
(0 \mathrm{dBZ})\end{array}$ & $\begin{array}{r}\Delta H \\
(10 \mathrm{dBZ})\end{array}$ \\
\hline \multirow[t]{3}{*}{ Cumulus } & 20 & 245740 & $480.6 \mathrm{~m}(23.0 \%)$ & $673.4 \mathrm{~m}(83.1 \%)$ & $1673.3 \mathrm{~m}(36.1 \%)$ \\
\hline & 30 & 215675 & $2178.4 \mathrm{~m}(24.8 \%)$ & $291.0 \mathrm{~m}(90.4 \%)$ & $1456.7 \mathrm{~m}(41.8 \%)$ \\
\hline & 40 & 207853 & $2281.3 \mathrm{~m}(24.7 \%)$ & $241.6 \mathrm{~m}(91.4 \%)$ & $1419.9 \mathrm{~m}(42.8 \%)$ \\
\hline \multirow[t]{3}{*}{ Deep convection } & 20 & 109582 & $429.8 \mathrm{~m}(40.5 \%)$ & $1610.4 \mathrm{~m}(92.4 \%)$ & $2592.8 \mathrm{~m}(51.1 \%)$ \\
\hline & 30 & 127164 & $2681.2 \mathrm{~m}(47.3 \%)$ & $838.9 \mathrm{~m}(95.2 \%)$ & $2255.2 \mathrm{~m}(54.7 \%)$ \\
\hline & 40 & 134588 & $3249.5 \mathrm{~m}(49.2 \%)$ & $572.6 \mathrm{~m}(95.6 \%)$ & $2117.2 \mathrm{~m}(55.2 \%)$ \\
\hline
\end{tabular}

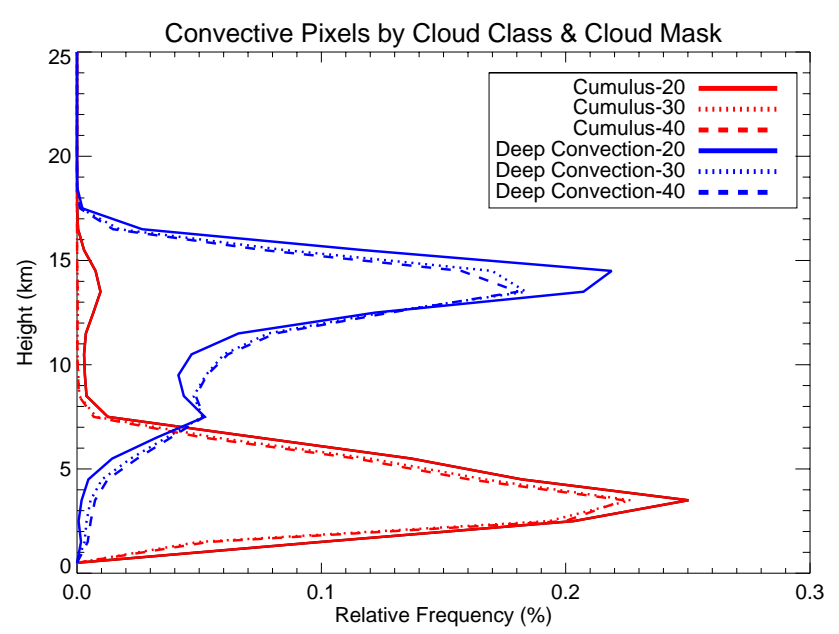

Fig. 1. Relative frequency of convective CTH, separated by cloud classification and radar mask cloud top height.

Finally, two levels of radar-reflectivity echo top height $(\mathrm{ETH})$ are identified: 0 and $10 \mathrm{dBZ}$. As mentioned in the introduction, these values were noted in Luo et al. (2008), and applied in Luo et al. (2009) to identify congestus clouds.

\section{Results}

Analyses of the convective echo characteristics are grouped in three sections. The first looks at statistics compiled from single CloudSat fields-of-view; this allows for profilespecific comparisons. The second section looks at coherent convective features along the CloudSat path; here identification focuses on the characteristics of specific cloud types. Finally, we will look at the applicability of the mean statistics obtained here for identifying congestus, similar to Luo et al. (2009)'s application of the Luo et al. (2008) means.

\subsection{Field-of-view analysis}

Figure 1 shows the relative frequency of convective $\mathrm{CTH}$, separated by cloud classification and cloud mask. Cumulus20 refers to the highest vertical bin with a cloud mask value of 20 or higher for a cloud identified as cumulus; similar definitions are used for cumulus-30, deep convection-20, etc. A vertical delineation between the two cloud types is apparent; the peak for the three cumulus curves lies around $4 \mathrm{~km}$, while the deep convection peaks lie near $14-15 \mathrm{~km}$. Cloud class does not uniquely distinguish deep and shallow clouds, however. Some clouds flagged as deep convection are seen to have CTH heights of $2-3 \mathrm{~km}$ above the surface. In addition, a weak cumulus- 20 peak is noted at $14 \mathrm{~km}$; no such peak is noted in cumulus-30, suggesting some are areas where the difference in height between cumulus-20 and cumulus30 may exceed $5 \mathrm{~km}$. Only slight differences are noted between cloud masks 30 and 40; the curves for cumulus-30 and cumulus-40 are nearly indistinguishable.

Table 1 lists CTH and ETH differences for congestus (CTH of 3 to $9 \mathrm{~km}$ and radar cloud base below $1 \mathrm{~km}$ ), separated by the six cloud classification/mask categories. The third column lists the number of fields-of-view. More congestus fields-of-view are identified as cumulus by the 2BCLDCLASS algorithm than as deep convection, at a rate of nearly two to one. Also, more cumulus-20 are identified as congestus than cumulus-40; this suggests a situation where the cumulus- $20 \mathrm{CTH}$ is greater than $3 \mathrm{~km}$ while cumulus- 40 is below $3 \mathrm{~km}$, or, a cumulus- 20 cloud has no areas reporting a cloud mask of 40 . Conversely, more deep convection-40 are identified as congestus than deep convection-20; this may be due to a deep convection-20 CTH greater than $9 \mathrm{~km}$ and deep convection-40 CTH less than $9 \mathrm{~km}$ (and thus identified as congestus here).

The fourth column of Table 1 lists the mean difference between CALIPSO and CloudSat CTH. Because the CALIPSO lidar is more sensitive to smaller particles than is the CloudSat radar, CTH is expected to be higher from CALIPSO. The mean CTH difference ranges from 0.4 to $3.2 \mathrm{~km}$ in 
Table 1. As expected, the mean CTH difference between CALIPSO and radar cloud mask $40 \mathrm{CTH}$ is higher than between CALIPSO and radar cloud mask $20 \mathrm{CTH}$. For cloud mask 20, the distance is smaller above pixels identified as deep convection than pixels identified as cumulus; for cloud masks 30 and 40, the distance is smaller above cumulus.

Column 4 also lists the percentage of cases with the appropriate cloud mask/classification where CALIPSO reports a cloud-top for the convective cell. This only occurs for about $24 \%$ of cumulus cases and $45 \%$ of deep convective cases. The majority of these missed pixels (see Appendix A) are due to the "extinguishment" of the lidar beam, where CALIPSO reports a cloud high up in the atmosphere but cannot see the convection below it. Appendix A also details the differences in missed observations between the current and previous versions of the merged CloudSat/CALIPSO product, most notably the decrease in false detections in the latest version.

The fifth column of Table 1 lists the difference between CloudSat CTH and $0 \mathrm{dBZ}$ ETH. The percentage values in this column show that a majority of convective pixels for both cloud types contain a $0 \mathrm{dBZ}$ echo within the cloud. This height difference ranges from 200-1600 m, with higher cloud mask values of CTH located nearer the $0 \mathrm{dBZ}$ ETH than lower values. The $0 \mathrm{dBZ}$ ETH is on average closer to cumulus CTH than to deep convective CTH. The final column is similar to column 5, except shows results for the $10 \mathrm{dBZ}$ ETH. As with $0 \mathrm{dBZ}$ ETH, the $10 \mathrm{dBZ}$ ETH is closer to the cumulus CTH than to deep convection CTH. The mean height difference is around $1500 \mathrm{~m}$ for cumulus-identified pixels, and around $2300 \mathrm{~m}$ for deep-convection-identified pixels. This is greater than for the $0 \mathrm{dBZ}$ ETH. However, less than half of cumulus-identified fields-of-view contain reflectivities greater than $10 \mathrm{dBZ}$, while slightly more than half of deep-convection-identified fields-of-view do. This may reveal the extent of the edges of convective clouds seen by CloudSat; non-precipitating edges of convective features would return smaller echoes.

These results summarize an instantaneous field-of-view perspective of congestus clouds. We now turn to a convective-feature analysis of the CloudSat cloud classification and mask.

\subsection{Convective feature analysis}

Here we define "convective feature" as a continuous swath of fields-of-view along the CloudSat path for which the cloud class is identified as either cumulus or deep convective. This definition does not distinguish individual convective cells; if two or more cells are located next to each other, this classification treats them as one continuous convective feature. An example of a convective feature can be seen in Fig. 2, which shows the returned radar power (top panel) and associated 2B-CLDCLASS classification (bottom panel) for a sample scan (orbit 2680, section 31) over the Pacific Ocean (http://

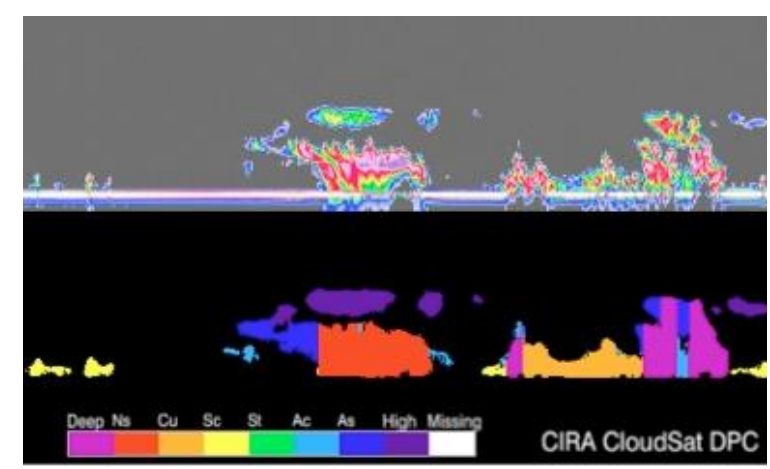

Fig. 2. Top: sample returned power scan from CloudSat. Bottom: associated 2B-CLDCLASS classification of the returned cells. $\mathrm{Cu}=$ cumulus, deep $=$ deep convection. Both images taken from the CloudSat online quicklook archive: http://www.cloudsat.cira. colostate.edu/dpcstatusQL.php.

www.cloudsat.cira.colostate.edu/dpcstatusQL.php). Though multiple narrow cells can be identified in the top panel, the cloud classification groups these all together into one cumulus feature (identified in orange on the bottom panel). The highest CTH among all the profiles in one convective feature is considered the convective feature's CTH.

Figure 3 shows the regional distribution of convective features identified using the CTH criteria described above. They seem to mirror the expected convective distribution in the tropics (Sassen and Wang 2008), with the exception of fewer congestus convective features noted over the West Pacific/maritime continent warm pool region. The lower amounts of congestus in this region are also reported in Rossow et al. (2005). Sassen and Wang (2008) also confirm a relative Maritime Continent void in both cumulus and deep convective clouds using one year of data. No difference was noted when plotting in terms of occurrence frequency (not shown) instead of total counts, suggesting no regional differences in congestus convective feature size.

Table 2 lists ETH difference for congestus convective features, separated by the same six cloud classification/mask categories used to characterize individual fields-of-view in Table 1. Only convective features made up entirely of cumulus- or deep-convective-identified pixels are included in Table 2, to allow for comparison of the two cloud type identifications; about $1.4 \%$ of the total convective features identified are made up of a combination of cumulus and deepconvective pixels. As before, more features are identified as cumulus than as deep convection. Dividing column 3 in Table 1 by column 3 in Table 2, it is clear that the ratio of cumulus fields-of-view to cumulus-convective features (6 to 1) is less than the ratio of deep convective fields-of-view to deep convective features (10 to 1 ). This is because deep convective features are larger horizontally than shallower cumulus features (Johnson et al., 1999). 

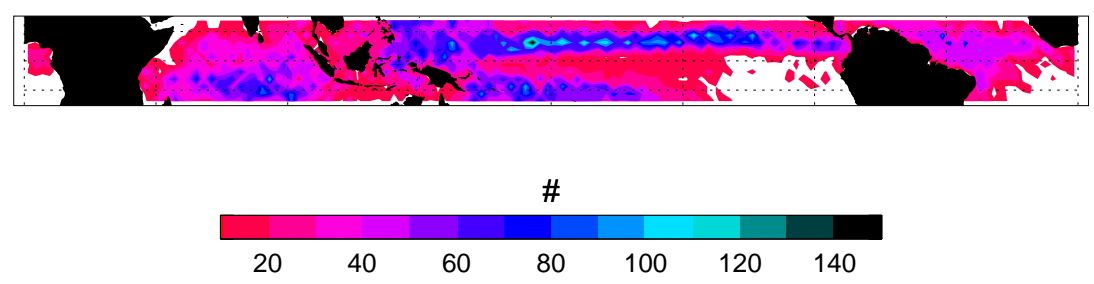

Fig. 3. Regional distribution of congestus convective features, contoured by the total number of observations over a $2.5^{\circ} \times 2.5^{\circ}$ grid box. White areas mark regions where fewer than ten congestus convective features are observed.

Table 2. CTH and ETH differences for contiguous congestus convective features, separated by the six cloud classification/mask categories.

\begin{tabular}{|c|c|c|c|c|c|}
\hline $\begin{array}{l}\text { Cloud } \\
\text { classification }\end{array}$ & $\begin{array}{r}\text { Cloud } \\
\text { mask }\end{array}$ & Counts & $\begin{array}{r}\Delta H \\
\text { (CALIPSO-CloudSat) }\end{array}$ & $\begin{array}{r}\Delta H \\
(0 \mathrm{dBZ})\end{array}$ & $\begin{array}{r}\Delta H \\
(10 \mathrm{dBZ})\end{array}$ \\
\hline \multirow[t]{3}{*}{ Cumulus } & 20 & 37679 & $262.9 \mathrm{~m}(50.2 \%)$ & $756.2 \mathrm{~m}(79.9 \%)$ & $1315.1 \mathrm{~m}(59.1 \%)$ \\
\hline & 30 & 32895 & $1132.6 \mathrm{~m}(53.0 \%)$ & $610.9 \mathrm{~m}(86.8 \%)$ & $1217.0 \mathrm{~m}(68.9 \%)$ \\
\hline & 40 & 32144 & $1213.4 \mathrm{~m}(53.4 \%)$ & $573.0 \mathrm{~m}(87.5 \%)$ & $1184.6 \mathrm{~m}(70.1 \%)$ \\
\hline \multirow[t]{3}{*}{ Deep convection } & 20 & 12552 & $288.1 \mathrm{~m}(58.6 \%)$ & $1124.1 \mathrm{~m}(89.5 \%)$ & $1949.2 \mathrm{~m}(70.0 \%)$ \\
\hline & 30 & 12714 & $1204.6 \mathrm{~m}(61.1 \%)$ & $868.7 \mathrm{~m}(90.0 \%)$ & $1756.2 \mathrm{~m}(74.6 \%)$ \\
\hline & 40 & 13186 & $1508.3 \mathrm{~m}(61.8 \%)$ & $817.8 \mathrm{~m}(89.0 \%)$ & $1711.4 \mathrm{~m}(74.2 \%)$ \\
\hline
\end{tabular}

According to Table 2, about $60 \%$ of deep convective features are associated with a CTH observed by CALIPSO; the number is slightly lower for cumulus features $(52 \%)$. This is to be expected since a cumulus feature, being closer to the ground, would have more space between it and the tropopause than a deep convective feature, and thus more room for another cloud such as thin cirrus or anvil clouds detectable by CALIPSO. The difference in height between CloudSat and CALIPSO is lower than in Table 1: about $900 \mathrm{~m}$ for cumulus and $1 \mathrm{~km}$ for deep convection.

The distance between the top of the convective feature and the highest $0 \mathrm{dBZ}$ height (column 5 in Table 2) is higher than for the single field-of-view comparison. The convective feature algorithm saves the smallest distance between CloudSat CTH and ETH for all pixels in the feature as the distance between these levels for the feature. The fact that the distance is higher for convective features than individual pixels, therefore, suggests that small convective features with larger CloudSat CTH-ETH differences are more numerous than large features with smaller CTH-ETH differences. This distance averages about $600 \mathrm{~m}$ for cumulus and $900 \mathrm{~m}$ for deep convection. Fewer convective features contain $0 \mathrm{dBZ}$ echoes than individual fields-of-view summarized in Table 1.

Finally, when comparing convective feature cloud height to $10 \mathrm{dBZ} \mathrm{ETH}$, we see that more convective features than individual fields of view contain 10-dBZ echoes, in contrast to the relation between 0 -dBZ echoes. Unlike for the fieldsof-view analysis, a majority (60-70\%) of cumulus convective features contain a 10-dBZ echo; $72 \%$ of deep convective features contain echoes greater than $10 \mathrm{dBZ}$. The average distance in CTH for cumulus-identified convection is about $1.2 \mathrm{~km}$, and for deep convective features is about $1.8 \mathrm{~km}$.

\subsection{Quantitative identification of congestus}

We now return to the three criteria used to identify congestus in Luo et al. (2009), as described in the introduction. Rather than comparing all three cloud-mask values, we will only use a cloud mask $=30$ for this section, as this was the value used in the Luo et al. (2009) study. The mean values in Table 2 appear to corroborate the criteria values; the mean difference between CTH and $0 \mathrm{dBZ}$ ETH is less than $1 \mathrm{~km}$, and between $\mathrm{CTH}$ and $10 \mathrm{dBZ}$ ETH is less than $2 \mathrm{~km}$. The mean deep convective radar-lidar difference is slightly more than $1 \mathrm{~km}$, however. For the Luo et al. (2009) identification method to be considered effective for congestus clouds in general, there must be a majority of features that satisfy all three requirements.

A total of 46276 congestus convective features were identified using the cloud mask 30 criteria (including 677 with a combination of cumulus- deep-convection-identified FOVs). However, 6993 of these (15.1\%) contain no CALIPSO measurements in the column at all, and for 11864 of the remaining $(25.6 \%)$ CALIPSO sees a separate cloud above the convectve feature, but not the convective feature itself. Including these missed-cloud cases (over $40 \%$ of total congestus convective features) would dominate the following results, and as such Table 3 and Fig. 4 only include the remaining 27419 congestus convective features $(59.3 \%)$ where CALIPSO views the same convective feature. 
Table 3. Number of cells that satisfy Luo et al. (2009) requirements. Only convective cells whose cloud-tops were identified by CALIPSO (about $59.3 \%$ of total observed cases) are included.

\begin{tabular}{lrrrrr}
\hline Cloud type & Total & $\begin{array}{r}\text { With lidar } \\
\Delta H<1 \mathrm{~km}\end{array}$ & $\begin{array}{r}\text { With 0dBZ } \\
\Delta H<1 \mathrm{~km}\end{array}$ & $\begin{array}{r}\text { With } 10 \mathrm{dBZ} \\
\Delta H<2 \mathrm{~km}\end{array}$ & $\begin{array}{r}\text { All three } \\
\text { requirements }\end{array}$ \\
\hline $\begin{array}{l}\text { Cumulus only } \\
\text { Deep convection only }\end{array}$ & 17446 & $14357(82.3 \%)$ & $14710(84.3 \%)$ & $12052(69.1 \%)$ & $10611(60.8 \%)$ \\
$\begin{array}{l}\text { Combination } \\
\text { cumulus/deep } \\
\text { convection }\end{array}$ & 468 & $5624(72.4 \%)$ & $5701(73.4 \%)$ & $4231(54.5 \%)$ & $3371(43.4 \%)$ \\
\hline Total & & & $399(85.3 \%)$ & $333(71.2 \%)$ & $272(58.1 \%)$ \\
\hline
\end{tabular}

Table 3 shows information for features meeting these criteria. Appropriate statistics for convective features made up of a combination of cumulus and deep-convective fields of view are also included in this table. A majority of features satisfy at least one individual requirement, and a majority of cumulus and mixed-cumulus-deep convective features satisfy all three. However, less than half $(43.4 \%)$ of features for the deep convective cloud type satisfy all three. The main limiting factor appears to be the $10 \mathrm{dBZ}$ ETH threshold. Table 2 shows that only $60-75 \%$ of contiguous convective features contain a $10 \mathrm{dBZ}$ ETH; only $55-70 \%$ of convective features have a $10 \mathrm{dBZ}$ ETH within $2 \mathrm{~km}$ of CloudSat CTH (Table 3). (While a $10 \mathrm{dBZ}$ echo may be important for determining active convective cores, or convective areas producing precipitation, this study focuses on all convective congestus clouds, and as such a $10 \mathrm{dBZ}$ echo would not be expected in all convective features). The low performance of the deep-convection-only convective features is especially confusing, given that this cloud type is typically associated with more vigorous convection than the cumulus cloud type. Finally, when including the convective features not observed by CALIPSO, the number of features satisfying all criteria plummets to $31 \%$. Overall, these results suggest than an identification scheme based purely on thresholding on lidar CTH and radar ETH values may miss over half of all observed congestus.

Figure 4 shows the regional distribution of convective features that satisfy the Luo et al. (2009) criteria. Blue and green colors mark areas where a majority of features satisfy the given criteria; purple and red mark where less than $50 \%$ of features satisfy. Comparing Figs. 3 and 4, it is again clear that the $10 \mathrm{dBZ}$ ETH threshold is the main limiting factor in determining the existence of congestus cloud; applying this criterion alone misses over $50 \%$ of congestus convective features over parts of the maritime continent/West Pacific. (Near the islands of the Maritime Continent, the fraction of congestus satisfying each criterion appears to decrease; as this study looks at ocean-only scenes as identified in the 2BCLDCLASS algorithm, no data is available over the larger islands in the Indonesian region, and this decrease should be considered an artifact).
Also, more convective features fit any combination of criteria over the central Pacific than over the maritme continent/West Pacific in Fig. 4. Zonal differences are apparent, but no strong pattern appears over these regions in the meridional direction. On the other hand, zonal and meridional patterns are noted in the total count distirbutions in Fig. 3, corresponding to well-known areas of enhanced convection (Intertropical Convergence Zone, South Pacific Convergence Zone, etc.). Comparison of Figs. 3 and 4 suggests that congestus convective features meeting the convective criteria of Luo et al. (2009) may be related to a zonal phenomenon such as the Walker circulation. Further investigation is warranted to identify the large-scale dynamic features that could affect the strength of observed congestus in comparison with the Luo et al. (2009) method.

\section{Summary and conclusions}

This study describes characteristics of cloud- and echo-top height associated with tropical oceanic congestus clouds. In addition to checking three different cloud masks derived from the CloudSat GEOPROF product, we looked at the distance from CTH to CALIPSO CTH, $0 \mathrm{dBZ}$ ETH, and $10 \mathrm{dBZ}$ ETH. These three heights were used in Luo et al. (2008) to describe tall convective cells.

In a profile-by-profile analysis, a majority of cells of both cloud types contain a $0 \mathrm{dBZ}$ echo; however, less than half of cumulus-identified fields-of-view have echoes greater than $10 \mathrm{dBZ}$. A majority of contiguous convective features contain a 10-dBZ echo. A majority of features also satisfy one of the three requirements for congestus clouds used in Luo et al. (2009).

When applying these criteria, however, only about $31 \%$ of convective features satisfy all three requirements. The largest contributing factor is the CALIPSO CTH requirement, with over $40 \%$ of convective features not observed by CALIPSO. $55 \%$ of the remaining cells satisfy all three criteria. Analyses of convective features using this identification would therefore be skewed toward the more vigorous congestus convection (i.e., higher radar reflectivities) rather than being 

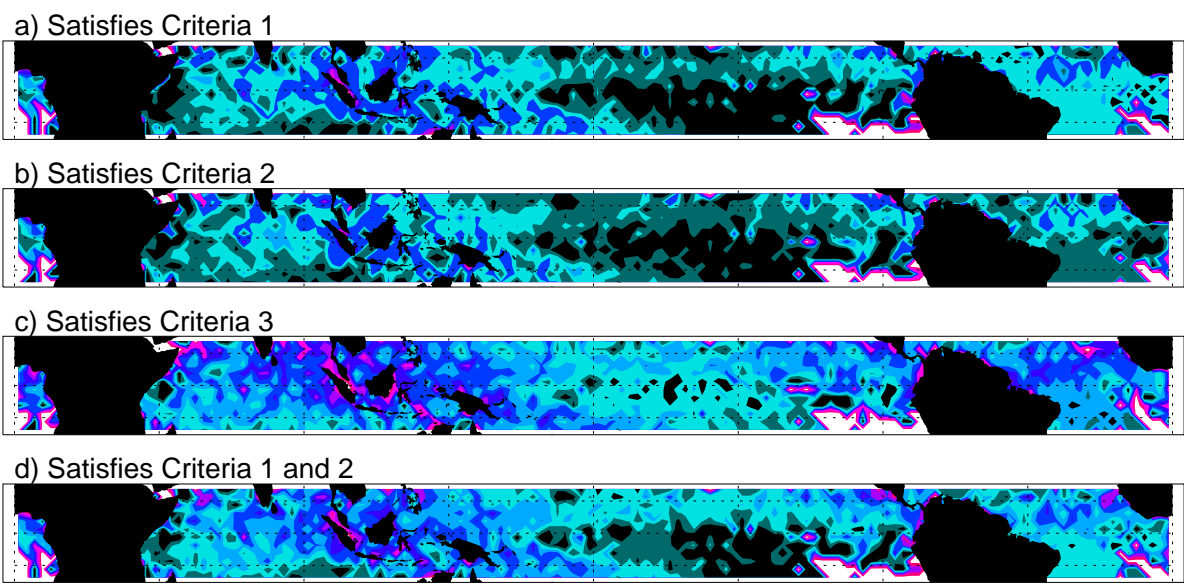

e) Satisfies Criteria 1 and 3
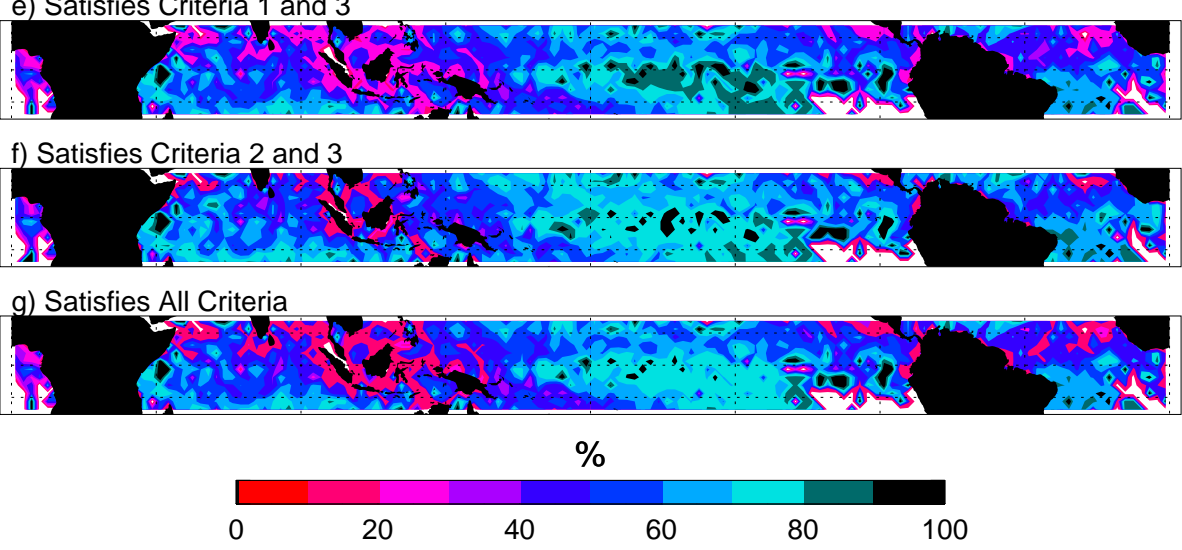

Fig. 4. Percentage of convective features in $2.5^{\circ}$ longitude by $2.5^{\circ}$ latitude boxes that satisfy the three Luo et al. (2009) criteria: (1) difference between CloudSat and CALIPSO CTH of less than $1 \mathrm{~km},(2)$ difference between CloudSat CTH and $0 \mathrm{dBZETH}$ of less than $1 \mathrm{~km}$, and (3) difference between CloudSat and $10 \mathrm{dBZETH}$ of less than $2 \mathrm{~km}$. White areas mark regions where no congestus convective features are observed.

representative of congestus as a whole. The criteria appear to do a better job of identifying congestus convection over the eastern and central Pacific than over the Western Pacific and Maritime Continent regions. This may relate to the role of subsidence in the Walker Circulation, capping strong cells that would otherwise rise to become deeper clouds (Sherwood et al., 2010).

This paper examines the conditions for applying the mean threshold statistics from Luo et al. (2008) to identify congestus. The applicability of the method, of course, depends on the phenomena of interest. The quantitative method from Luo et al. (2009) identifies strong congestus features; i.e., those with high $(>10 \mathrm{dBZ})$ reflectivity and small differences between CTH and ETH. These may be more useful in identifying transient congestus (mid-level convection rising to become a deeper cloud). Identification of congestus features in general may be better accomplished by the CLDCLASS algorithm of Sassen and Wang (2008), as well as using the 3 to $9 \mathrm{~km}$ height characteristics used in Jensen and Del Genio
(2006) to separate congestus from shallow and deep clouds. Together, these methods identify both weaker and stronger congestus convective features, yielding a larger set of congestus clouds for analysis.

\section{Appendix A}

\section{Change in results based on using 2B-GEOPROF-LIDAR versions P1_R04 and P2_R04}

The Atmospheric Chemistry and Physics Discussions version of this paper was submitted in January 2011 using data from 2B-GEOPROF-LIDAR data release P1_R04. In October 2010, the CloudSat science team released version P2_R04, following the release of a new version of CALIPSO data products. The intent of the new version was to reduce the number of false cloud detections (Lidar Level 2 Vertical 
Table A1. Comparison of values from Tables 1 to 3 affected by using version P1_R04 instead of P2_R04.

\begin{tabular}{lrr}
\hline Table, Row, Column & Values using P1 & Values using P2 \\
\hline Table 1, Row 3, Column 4 & $4576.8 \mathrm{~m}(64.6 \%)$ & $2178.4 \mathrm{~m}(24.8 \%)$ \\
Table 1, Row 3, Column 6 & $4467.6 \mathrm{~m}(80.5 \%)$ & $2681.2 \mathrm{~m}(47.3 \%)$ \\
Table 2, Row 3, Column 4 & $1127.5 \mathrm{~m}(54.5 \%)$ & $1132.6 \mathrm{~m}(53.0 \%)$ \\
Table 2, Row 6, Column 4 & $1225.0 \mathrm{~m}(62.3 \%)$ & $1204.6 \mathrm{~m}(61.1 \%)$ \\
Table 3, Row 2, Column 3 & $14213(59.2 \%)$ & $14357(82.3 \%)$ \\
Table 3, Row 2, Column 4 & $19832(82.6 \%)$ & $14710(84.3 \%)$ \\
Table 3, Row 2, Column 5 & $15879(66.1 \%)$ & $12052(69.1 \%)$ \\
Table 3, Row 2, Column 6 & $10498(43.7 \%)$ & $10611(60.8 \%)$ \\
Table 3, Row 3, Column 3 & $5461(59.0 \%)$ & $5624(72.4 \%)$ \\
Table 3, Row 3, Column 4 & $6759(73.0 \%)$ & $5701(73.4 \%)$ \\
Table 3, Row 3, Column 5 & $5014(54.2 \%)$ & $4231(54.5 \%)$ \\
Table 3, Row 3, Column 6 & $3283(35.5 \%)$ & $3371(43.4 \%)$ \\
Table 3, Row 4, Column 3 & $326(59.8 \%)$ & $343(73.3 \%)$ \\
Table 3, Row 4, Column 4 & $460(84.4 \%)$ & $399(85.3 \%)$ \\
Table 3, Row 4, Column 5 & $380(69.7 \%)$ & $333(71.2 \%)$ \\
Table 3, Row 4, Column 6 & $258(47.3 \%)$ & $272(58.1 \%)$ \\
Table 3, Row 5, Column 3 & $20000(59.1 \%)$ & $20324(79.1 \%)$ \\
Table 3, Row 5, Column 4 & $27051(80.0 \%)$ & $20810(81.0 \%)$ \\
Table 3, Row 5, Column 5 & $21273(62.9 \%)$ & $16616(64.7 \%)$ \\
Table 3, Row 5, Column 6 & $14039(41.5 \%)$ & $14254(55.5 \%)$ \\
\hline
\end{tabular}

Feature Mask Product, CALIPSO Quality Statement, http://eosweb.larc.nasa.gov/PRODOCS/calipso/Quality\{_\} Summaries/CALIOP\{_\}L2VFMProducts\{_\}3.01.html). Given that this study focuses on active convection primarily viewed by CloudSat, it was assumed that the change in product would not significantly affect the results of this study.

It is now clear, however, that this assumption was incorrect. Table A.1 lists the changes in Tables 1-3 for cloud mask 30 that result from changing which version was used. (Changes in pixel/cloud counts are not listed, as small data gaps were present in our local copy of the P1_R04 dataset that were not in the latest version.) The percentage of profiles where CALIPSO sees the cloud-top of the convective pixel (Table 1) range from $65-80 \%$, compared to $25-47 \%$ for the latest version. However, the average distance between CALIPSO CTH and CloudSat CTH increases by about $2 \mathrm{~km}$. These results suggest that what was considered a continuous cloud in P1_R04 is now recognized as two separate clouds. Since the latest product also increases missed detections (Tanelli, 2011), it is unclear whether the change from one to more than one cloud layer is due to a false detection in P1_R04 or a missed detection in P2_R04.

When considering convective features instead of pixels (Table 2), the use of the latest version decreases the number of features for which CALIPSO reports a CTH; however, this change is slight, on the order of $1.5 \%$ difference. The mean difference between lidar and radar $\mathrm{CTH}$ is also mostly unchanged, on the order of tens of meters.

As discussed in Sect. 3.3, only $59.3 \%$ of convective features identified contained a CALIPSO CTH using P2_R04. In using P1_R04, this number climbs to $75.5 \%$, meaning thousands of convective features that had concurrent CALIPSO CTHs in P1_R04 are no longer visible from CALIPSO. The effect of this change is shown in Table A1 in its comparison with values from Table 3 . Though the percentage of viewed cloud-top heights changes, the number of convective features with CALIPSO CTH less than $1 \mathrm{~km}$ (Table 3 Column 3) only changes slightly, lowering the percentage that satisfies this criteria from $72-82 \%$ to $59 \%$. Including more cells in P1_R04 does not change the percentage of features satisfying the 0 and $10 \mathrm{dBZ}$ criteria (Table 3 , Columns 4 and 5 ); the number of cells satisfying the criteria increases at the same rate as the number of total cells with a CALIPSO CTH increases.

The result of these changes is apparent in the comparison of Table 3, Column 6 values, which seem to mirror the changes in Table 3, Column 3. That is, the number of cells satisfying all three requirements in the two cases is about the same, but since more clouds have an associated CALIPSO CTH in P1_R04, the percentage of cells satisfying all three requirements drops from $55.5 \%$ to $41.5 \%$. When including all cells, even those with no observed CALIPSO CTH, the percentage of cells satisfying all three criteria is about $32 \%$, close to the $31 \%$ obtained using P2_R04.

As mentioned above, these changes to Tables 1 through 3 could have two causes: either a cloud that was mistakenly combined in P1_R04 is now accurately reported as two or more clouds in P2_R04, or a single cloud observed accurately in P1_R04 is now mistakenly reported as two or more clouds in P2_R04. The most telling result may be the difference (or lack thereof) in Columns 4 and 5 of Fig. 3. While the number of clouds for which CALIPSO observes a CTH increases, the percentage of cells satisfying the 0 and $10 \mathrm{dBZ}$ criteria remains the same. If one assumes P1_R04 is correct, the lidar-radar difference criteria suggests that the cells identified as two or more clouds in P2_R04 are weaker cells. If that were the case, it would follow that fewer cells would satisfy the 0 and $10 \mathrm{dBZ}$ criteria as well, which is disproven in Table A1. This suggests that the interpretation of these cells in the latest version (where a cloud above the convective cell extinguishes the lidar beam before reaching the convective cell) is more likely.

Acknowledgements. The research described in this paper was carried out at the Jet Propulsion Laboratory, California Institute of Technology, under a contract with the National Aeronautics and Space Administration. It was supported by the NASA Making Earth Science Data Records for Use in Research Environments (MEaSUREs) project. (C) 2011 California Institute of Technology. Government sponsorship acknowledged.

Edited by: T. J. Dunkerton 


\section{References}

Chen, Y. and Del Genio, A. D.: Evaluation of tropical cloud regimes in observations and a general circulation model, Clim. Dynam., 32, 355-369, doi:10.1007/s00382-008-0386-6, 2009.

Jensen, M. P. and Del Genio, A. D.: Factors limiting convective cloud-top height at the ARM Nauru Island climate research facility, J. Climate, 19, 2105-2117, 2006.

Johnson, R. H., Richenbach, T. M., Rutledge, S. A., Ciesielski, P. E., and Schubert, W. H.: Trimodal characteristics of tropical convection, J. Climate, 12, 2397-2418, 1999.

Khouider, B. and Majda, A. J.: A simple multicloud parameterization for convectively coupled active waves. Part I. Linear analysis, J. Atmos. Sci., 63, 1308-1323, 2006.

Kikuchi, K. and Takayabu, Y. N.: The development of organized convection associated with the MJO during TOGA COARE IOP: trimodal characteristics, Geophys. Res. Lett., 31, L10101, doi:10.1029/2004GL019601, 2004.

Luo, Z. Z., Liu, G. Y., and Stephens, G. L.: CloudSat adding new insight into tropical penetrating convection, Geophys. Res. Lett., 35, L19819, doi:10.1029/2008GL035330, 2008.

Luo, Z. Z., Liu, G. Y., Stephens, G. L., and Johnson, R. H.: Terminal versus transient cumulus congestus: a CloudSat perspective, Geophys. Res. Lett., 36, L05808, doi:10.1029/2008GL036927, 2009.

Mace, G. G., Zhang, Q., Vaughan, M., Marchand, R., Stephens, G., Trepte, C., and Winker, D.: A description of hydrometeor layer occurrence statistics derived from the first year of merged Cloudsat and CALIPSO data, J. Geophys. Res., 114, D00A26, doi:10.1029/2007JD009755, 2009.

Marchand, R. T., Mace, G. G., Ackerman, T., and Stephens, G.: Hydrometeor detection using CloudSat: an Earth-orbiting $94 \mathrm{GHz}$ cloud radar, J. Atmos. Ocean. Tech., 25, 519-533, 2008.
Mapes, B., Tulich, S., Lin, J., and Zuidema, P.: The mesoscale convection life cycle: building block or prototypes for largescale tropical waves?, Dynam. Atmos. Oceans, 42, 3-29, doi:10.1016/j.dynatmoce.2006.03.003, 2006.

Rossow, W. B., Tselioudis, G., Polak, A., and Jakob, C.: Tropical climate described as a distribution of weather states indicated by distinct mesoscale cloud property mixtures, Geophys. Res. Lett., 32, L21812, doi:10.1029/2005GL024584, 2005.

Sassen, K. and Wang, Z.: Classifying clouds around the globe with the CloudSat radar: 1-year of results, Geophys. Res. Lett., 35, L04805, doi:10.1029/2007GL032591, 2008.

Sherwood, S. C., Roca, R., Weckwerth, T. M., and Andronova, N. G.: Tropospheric water vapor, convection, and climate, Rev. Geophys., 48, RG2001, doi:10.1029/2009RG000301, 2010.

Stephens, G. L., Vane, D. G., Tanelli, S., Im, E., Durden, S., Rokey, M., Reinke, D., Partain, P., Mace, G. G., Austin, R., L'Ecuyer, T., Haynes, J., Lebsock, M., Suzuki, K., Waliser, D., Wu, D., Kay, J., and Gettelman, A.: CloudSat mission: performance and early science after the first year of operation, J. Geophys. Res., 113, D00A18, doi:10.1029/2008JD009982, 2008.

Tanelli, S.: Interactive comment on "Revised identification of tropical oceanic cumulus congestus as viewed by CloudSat" by S. P. F. Casey et al., Atmos. Chem. Phys. Discuss., 11, C9995-C9999, 2011.

Tanelli, S., Durden, S. L., Im, E., Pak, K. S., Reinke, D. G., Partain, P., Haynes, J. M., and Marchand, R. T.: CloudSat's cloud profiling radar after two years in orbit: performance, calibration, and processing, IEEE T. Geosci. Remote, 46, 11, 3560-3573, 2008.

Tromeur, E. and Rossow, W. B.: Interaction of the deep convection with the large scale circulation in the MJO, J. Climate, 23, 7, 1837-1853, 2010.

Winker, D. M., Vaughan, M. A., Omar, A., Hu, Y. X., Powell, K. A., Liu, Z. Y., Hunt, W. H., and Young, S. A.: Overview of the CALIPSO mission and CALIOP data processing algorithms, J. Atmos. Ocean. Tech., 26, 11, 2310-2323, 2009. 